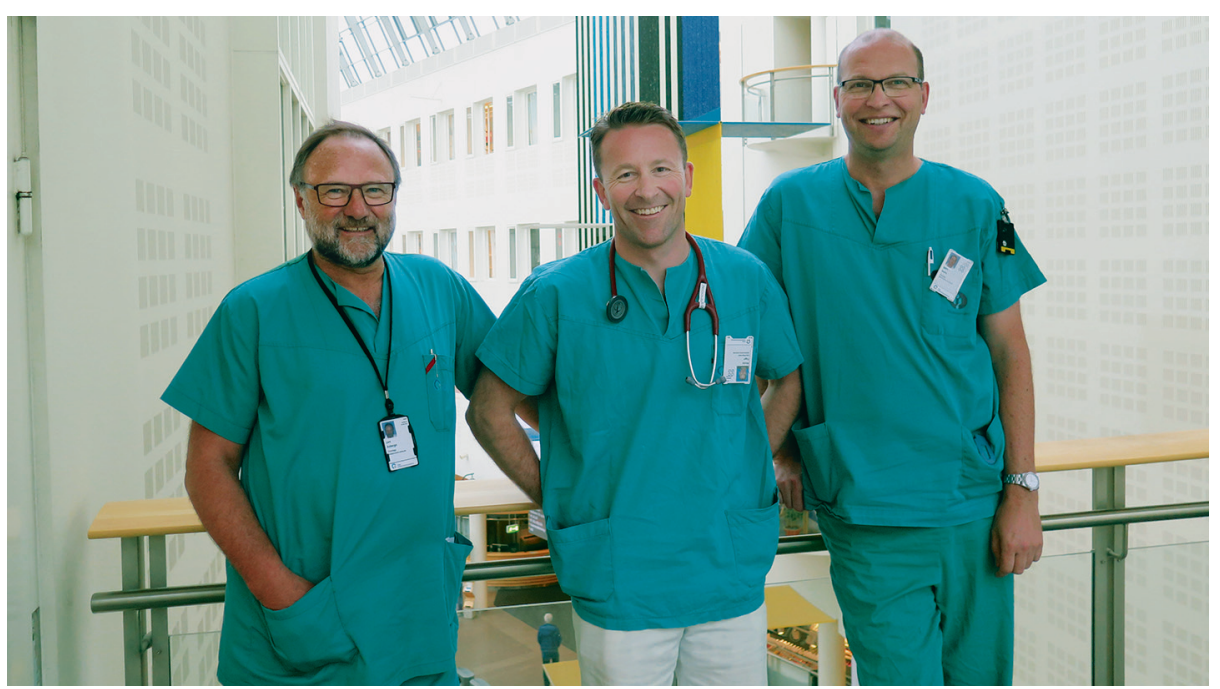

Fra venstre Lars Aaberge, Nicolai Kloumann Tegn og Bjørn Bendz. Foto: Pirritta Nyberg

\title{
Hjerteinfarktpasienter over 80 år bør behandles på samme måte som yngre
}

Pasienter over 80 år med hjerteinfarkt kan ha stor nytte av invasiv behandling i tillegg til annen medisinsk behandling. Dette viser en norsk studie som nylig er publisert i The Lancet.

Hjerteinfarkt uten ST-elevasjon og ustabil angina pectoris er vanlige årsaker til sykehusinnleggelse av eldre. Likevel finnes det få studier om nytten av invasiv behandling, dvs. hjertekateterisering, hos eldre. I praksis har man derfor vært tilbakeholden med slik behandling hos pasienter over 80 år. En norsk studie som nylig er publisert i det prestisjetunge tidsskriftet The Lancet, viser at også pasienter over 80 år har god nytte av invasiv behandling ved hjerteinfarkt (1).

Studien omfattet 457 pasienter over 80 år som ble innlagt ved 16 ulike lokalsykehus pga. hjerteinfarkt uten ST-elevasjon eller ustabil angina pectoris. Pasientene ble randomisert til enten overføring til Rikshospitalet for hjertekateterisering eller til ordinær medisinsk behandling ved lokalsykehuset. Median oppfølgingstid var 1,5 år. Gruppen som ble henvist til invasiv behandling, hadde lavere risiko for død, hjerteinfarkt, hjerneslag eller behov for akutt hjertekateterisering enn dem som ble behandlet på lokalsykehus (hasardratio 0,53; $95 \% \mathrm{KI}$ 0,35-0,76), men effekten avtok med økende alder. Det var ingen signifikant forskjell i blødningskomplikasjoner.

- Til nå har klinikere vært usikre på håndteringen av eldre pasienter med hjerteinfarkt uten ST-elevasjon eller ustabil angina pectoris pga. mangel på dokumentert nytte og risiko, sier Bjørn Bendz, som er overlege ved Kardiologisk avdeling ved Oslo universitetssykehus, Rikshospitalet og sisteforfatter av artikkelen. - Studien er den første som har randomisert pasienter over 80 år med hjerteinfarkt uten ST-elevasjon og ustabil angina pectoris, sier han.

- Studien viser at pasienter over 80 år med hjerteinfarkt bør håndteres på samme måte som yngre, noe som ikke er tilfellet i dag. En 80-åring har en forventet levetid på 9-10 år, og studien har derfor stor medisinsk og samfunnsøkonomisk interesse, sier Bendz.

\section{Kardiogeriatrisk forskning}

Studien kom i stand etter at Lars Aaberge, Knut Endresen og Bjørn Bendz ved Kardiologisk avdeling, Rikshospitalet stilte spørsmålet om eldre bør behandles på lik linje med yngre når de får hjerteinfarkt. Nicolai Tegn ble engasjert som ph.d.-kandidat. Michael Abdelnoor, som har lang erfaring med epidemiologisk og klinisk forskning, ble med som metode- og analyseekspert og Anette Hyem Ranhoff ved Universitetet i Bergen som geriater. De andre forfatterne var leger ved lokalsykehusene og Rikshospitalet.

\section{Kaveh Rashidi}

Tidsskriftet

\section{Litteratur}

1. Tegn N, Abdelnoor M, Aaberge L et al. Invasive versus conservative strategy in patients aged 80 years or older with non-ST-elevation myocardial infarction or unstable angina pectoris (After Eighty study): an open-label randomised controlled trial. Lancet 2016; 387: 1057-65.

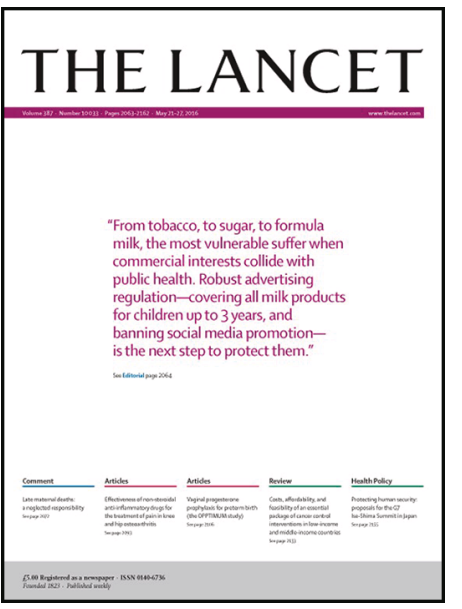

Artikkelen ble publisert i det prestisjetunge tidsskriftet The Lancet i mars 2016 